\title{
Supplementary material for the manuscript "Simulating oceanic radiocarbon with the FAMOUS GCM: implications for its use as a proxy for ventilation and carbon uptake"
}

Jennifer E. Dentith ${ }^{1}$, Ruza F. Ivanovic ${ }^{1}$, Lauren J. Gregoire ${ }^{1}$, Julia C. Tindall ${ }^{1}$, Laura F. Robinson ${ }^{2}$, and Paul J. Valdes ${ }^{3}$

${ }^{1}$ School of Earth and Environment, University of Leeds, Leeds, UK, LS2 9JT

${ }^{2}$ School of Earth Sciences, University of Bristol, Bristol, UK, BS8 1RJ

${ }^{3}$ School of Geographical Sciences, University of Bristol, Bristol, UK, BS8 1SS

Correspondence to: Jennifer E. Dentith (eejed@leeds.ac.uk) 


\section{Technical note}

For future scientific application of the isotope-enabled model, readers may wish to implement an additional modification ("mod") file to revise the ${ }^{14} \mathrm{C}$ half-life downwards from $5730 \pm 40$ years (Godwin, 1962) to $5700 \pm 30$ years (Audi et al., 2003), as per the Ocean Model Intercomparison Project's (OMIP) biogeochemical protocol (Orr et al., 2017). All of the results in this study are based on the now-outdated half-life of 5730 years, following the earlier Ocean CarbonCycle Model Intercomparison Project (OCMIP) protocol (Orr et al., 2000) and the abiotic legacy code (Palmer, 1998).

\section{Additional tables}

Table S1: Number of pre-bomb $\Delta^{14} \mathrm{C}$ data points in the compilation of Graven et al. (2012b) binned according to the vertical levels in FAMOUS.

\begin{tabular}{cc}
\hline Water depth $(\mathrm{m})$ & Number of data points \\
\hline 0 to 10 & 67 \\
10 to 20 & 2 \\
20 to 30 & 0 \\
30 to 40 & 2 \\
40 to 55 & 2 \\
50 to 80 & 0 \\
80 to 120 & 1 \\
120 to 170 & 4 \\
170 to 250 & 8 \\
250 to 375 & 3 \\
375 to 550 & 9 \\
550 to 830 & 13 \\
830 to 1250 & 6 \\
1250 to 1800 & 13 \\
1800 to 2400 & 14 \\
2400 to 3000 & 13 \\
3000 to 3600 & 8 \\
3600 to 4250 & 4 \\
4250 to 4900 & \\
4900 to 5500 & \\
$5500+*$ & \\
\hline
\end{tabular}

* Not represented in the model, which has a maximum depth of approximately $5500 \mathrm{~m}$. 
Table S2: Coral and bivalve locations, record lengths, and original references.

\begin{tabular}{|c|c|c|c|c|c|c|c|c|}
\hline Identifier & Location & Latitude $\left({ }^{\circ} \mathrm{N}\right)$ & Longitude $\left({ }^{\circ} \mathrm{E}\right)$ & Depth (m) & Archive & Length of record & Number of measurements & Reference \\
\hline $\mathrm{B}$ & Bermuda & 32 & -64 & 0 & Coral & 1950 to 1983 & 35 & Druffel et al. (1989) \\
\hline $\mathrm{B}$ & Bermuda & 32 & -64 & 1410 & Coral & $\approx 1400^{1}$ to 2001 & $26^{2}$ & Lee at al. (2017) \\
\hline $\mathrm{BB}$ & Bay of Biscay & 46.9 & -5.3 & 691 & Coral & 1950 to 1985 & 19 & Montero-Serrano et al. (2013) \\
\hline G & Grimsey & 66 & -18 & 82 & Bivalve & 1935 to 2005 & 16 & Scourse et al. (2012) \\
\hline GB & German Bight & 54 & 7 & 37 & Bivalve & 1948 to 1990 & 20 & Weidman (1995) \\
\hline $\mathrm{GeB}$ & Georges Bank & 41 & -67 & 76 & Bivalve & 1939 to 1989 & 13 & Weidman and Jones (1993) \\
\hline $\mathrm{GrB}$ & Grand Banks & 44.13 & -52.93 & 0 & Coral & 1884 to 1991 & 12 & Sherwood et al. (2008) \\
\hline GrB & Grand Banks & 44.13 & -52.93 & 713 & Coral & 1879 to 2001 & 12 & Sherwood et al. (2008) \\
\hline HS & Hudson Strait & 60.5 & -61.4 & 0 & Coral & 1925 to 2000 & 18 & Sherwood et al. (2008) \\
\hline HS & Hudson Strait & 60.5 & -61.4 & 414 & Coral & 1941 to 1994 & 3 & Sherwood et al. (2008) \\
\hline $\mathrm{NE}$ & Northeast Channel & 42 & -65.5 & 0 & Coral & 1924 to 2002 & 26 & Sherwood et al. (2008) \\
\hline $\mathrm{NE}$ & Northeast Channel & 42 & -65.5 & $362.5^{3}$ & Coral & 1890 to 1983 & 14 & Sherwood et al. (2008) \\
\hline OG & Oyster Ground & 54 & 4 & 40 & Bivalve & 1928 to 1986 & 30 & Witbaard et al. (1994) \\
\hline$S$ & Siglufjörður & 66 & -19 & 22 & Bivalve & 1874 to 1991 & 17 & Weidman (1995) \\
\hline SB & Sable Bank & 44 & -61 & 35 & Bivalve & 1956 to 1981 & 15 & Kilada et al. (2007) \\
\hline $\mathrm{T}$ & Troms $\emptyset$ & 70 & 19 & 3 & Bivalve & 1940 to 1993 & 14 & Weidman (1995) \\
\hline
\end{tabular}

${ }^{1} 1441$ based on the coral's higher vertical extension rate and 1373 based on the coral's lower vertical extension rate.

${ }^{2} 19$ of which are between $\approx 1880$ and 2001 and 7 of which are between $\approx 1400$ and $\approx 1700$.

${ }^{3}$ Between $275 \mathrm{~m}$ and $450 \mathrm{~m}$. 


\section{Additional figures}

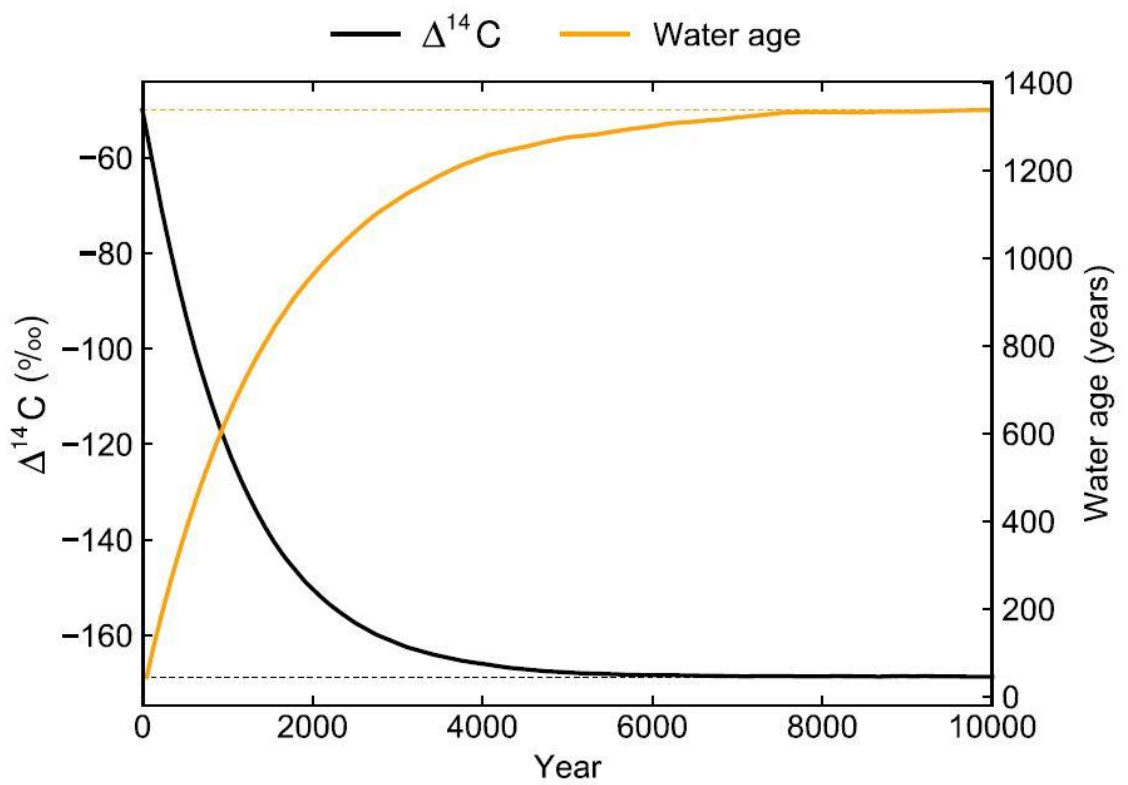

Figure S1: Global volume-weighted $\Delta^{14} \mathrm{C}$ (black) and water age (orange) integrals for the spin-up simulation. The solid lines show the transient isotopic ratios and the dashed lines show the values at equilibrium.

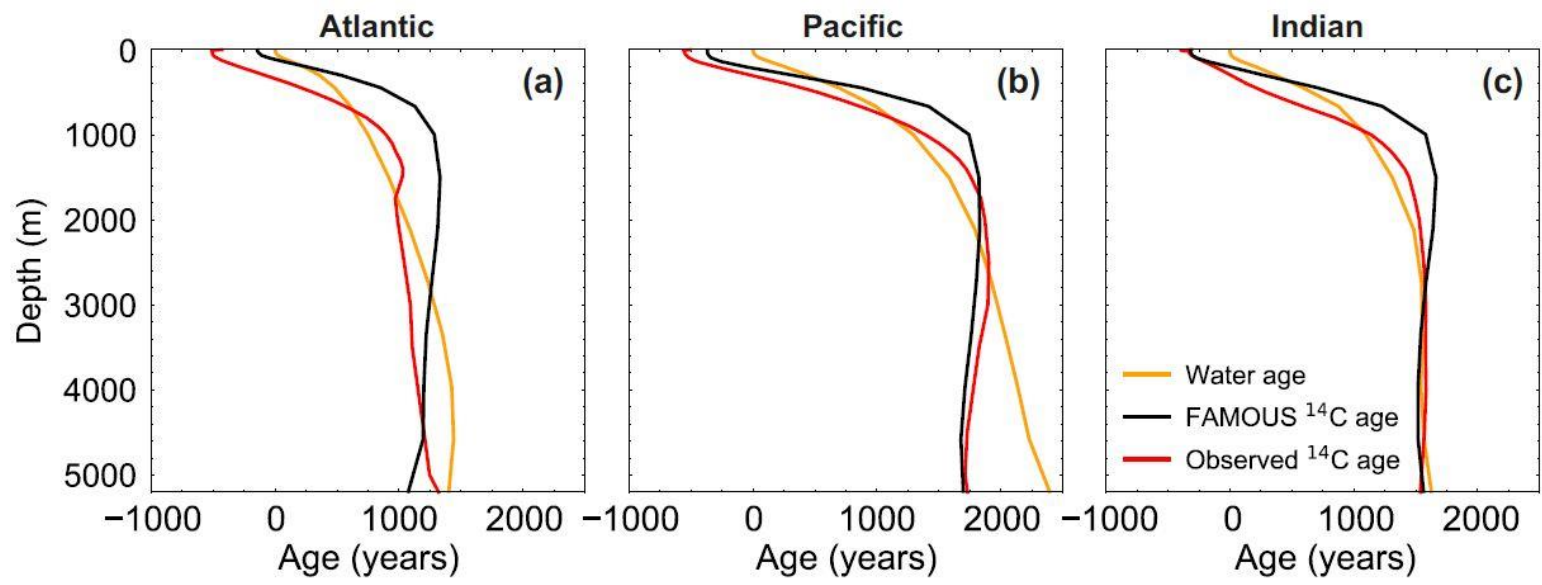

Figure S2: Basin-averaged depth profiles of ${ }^{14} \mathrm{C}$ age and water age during the 1990s: (a) Atlantic Ocean, (b) Pacific Ocean, and (c) Indian Ocean. The simulated ${ }^{14} \mathrm{C}$ age (black) is compared to the simulated water age (orange) and the ${ }^{14} \mathrm{C}$ age in the gridded GLODAP data (Key et al., 2004; red). 


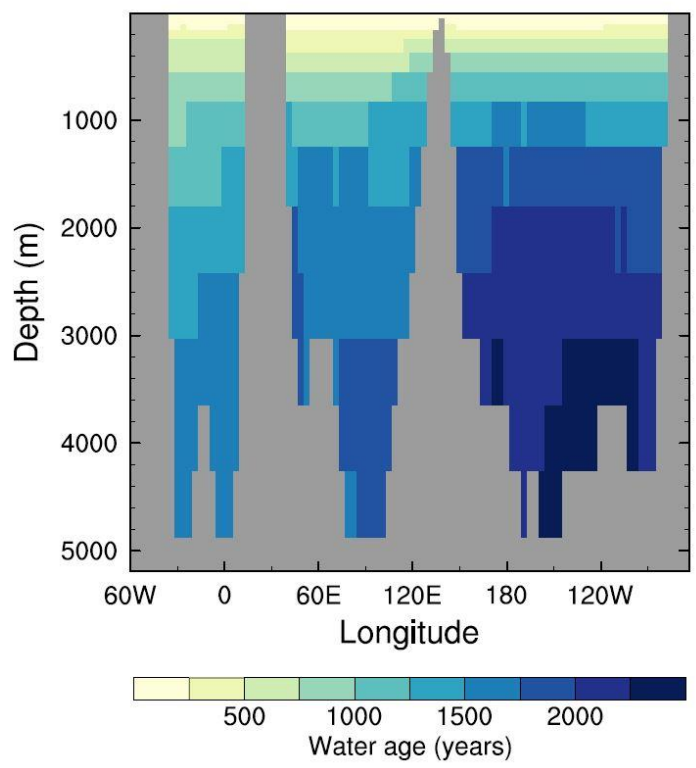

Figure S3: Idealised water age transect at $10^{\circ} \mathrm{S}$ at the end of the spin-up simulation (years 9900 to 10,000). 

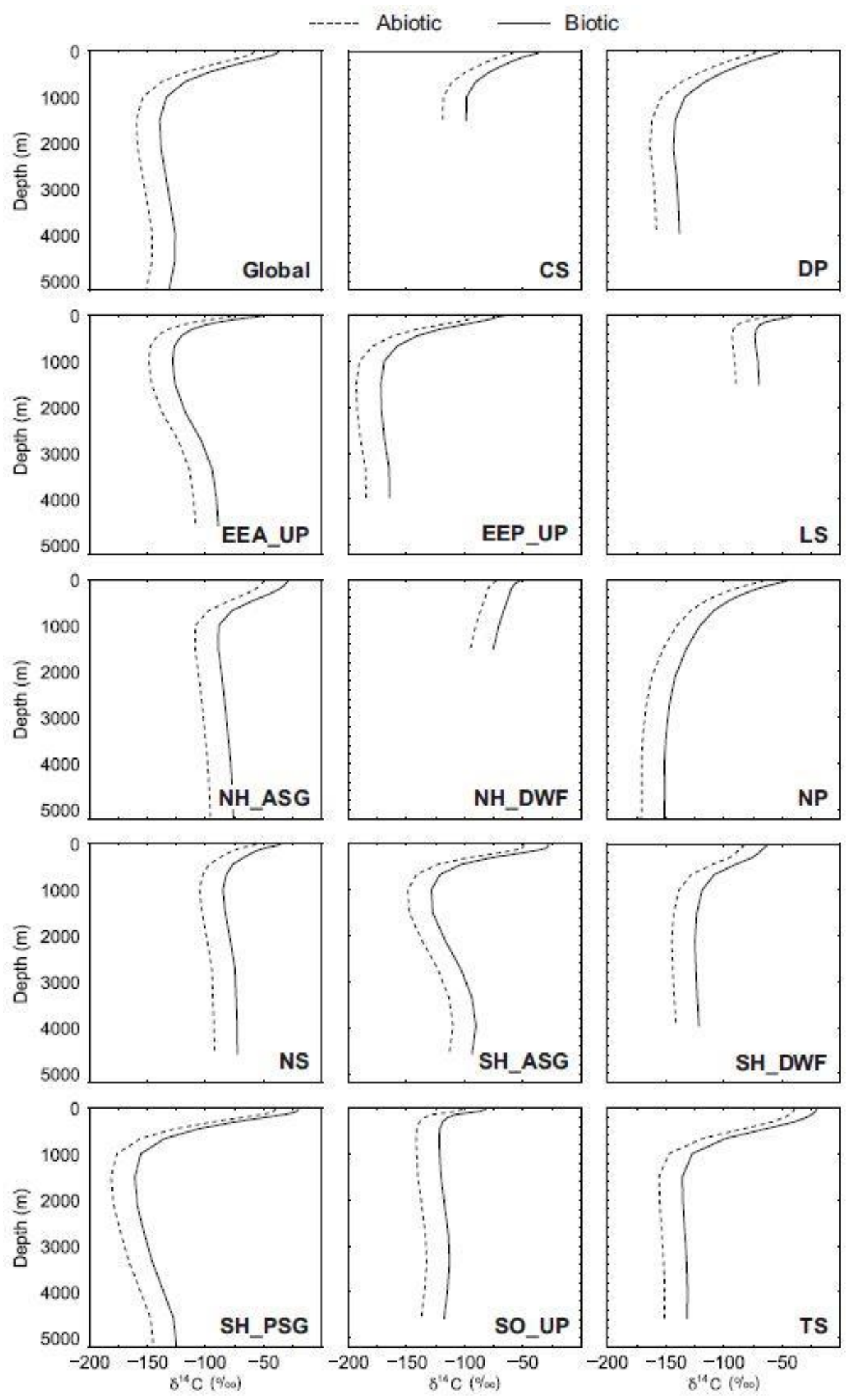

Figure S4: Global and regional depth profiles of abiotic (dashed) and biotic (solid) $\delta^{14} \mathrm{C}$ at the end of the spin-up simulation (years 9900 to 10,000). The regions are outlined in Figure 7 in the main manuscript: Caribbean Sea (CS), Drake Passage (DP), eastern equatorial Atlantic upwelling zone (EEA_UP), eastern equatorial Pacific upwelling zone (EEP_UP), Labrador Sea (LS), Northern Hemisphere Atlantic sub-tropical gyre (NH_ASG), Northern Hemisphere deep water formation region (NH_DWF), North Pacific (NP), Nova Scotia (NS), Southern Hemisphere Atlantic sub-tropical gyre (SH_ASG), Southern Hemisphere deep water formation region (SH_DWF), Southern Hemisphere Pacific subtropical gyre (SH_PSG), Southern Ocean upwelling zone (SO_UP), and Tasman Sea (TS). 

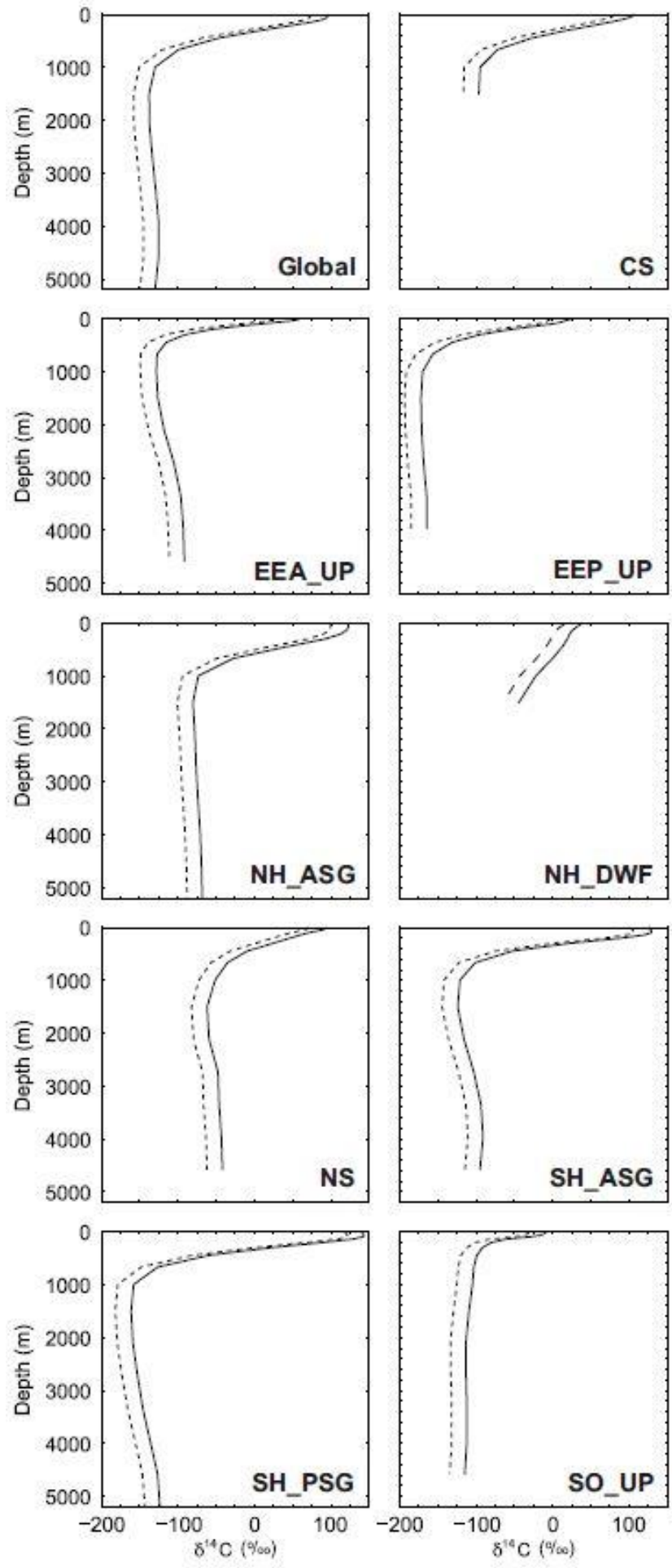

Abiotic

Biotic
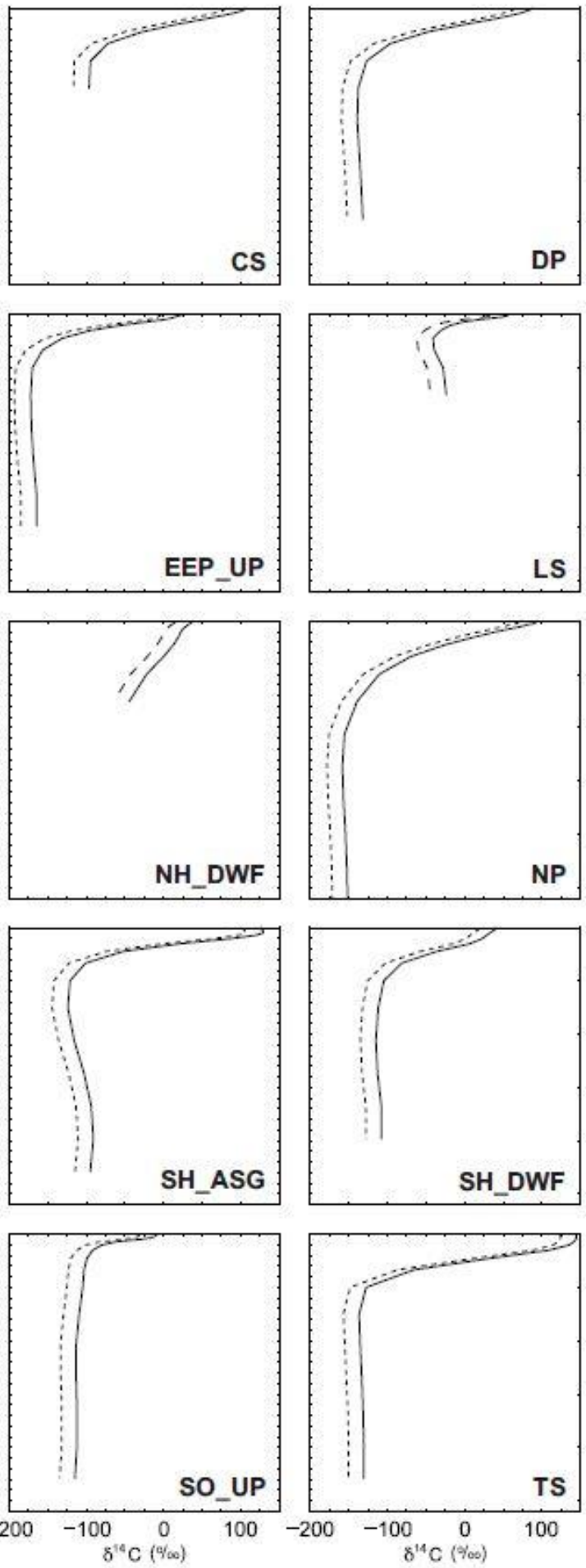

Figure S5: As for Figure S4, but for the 1990s. 

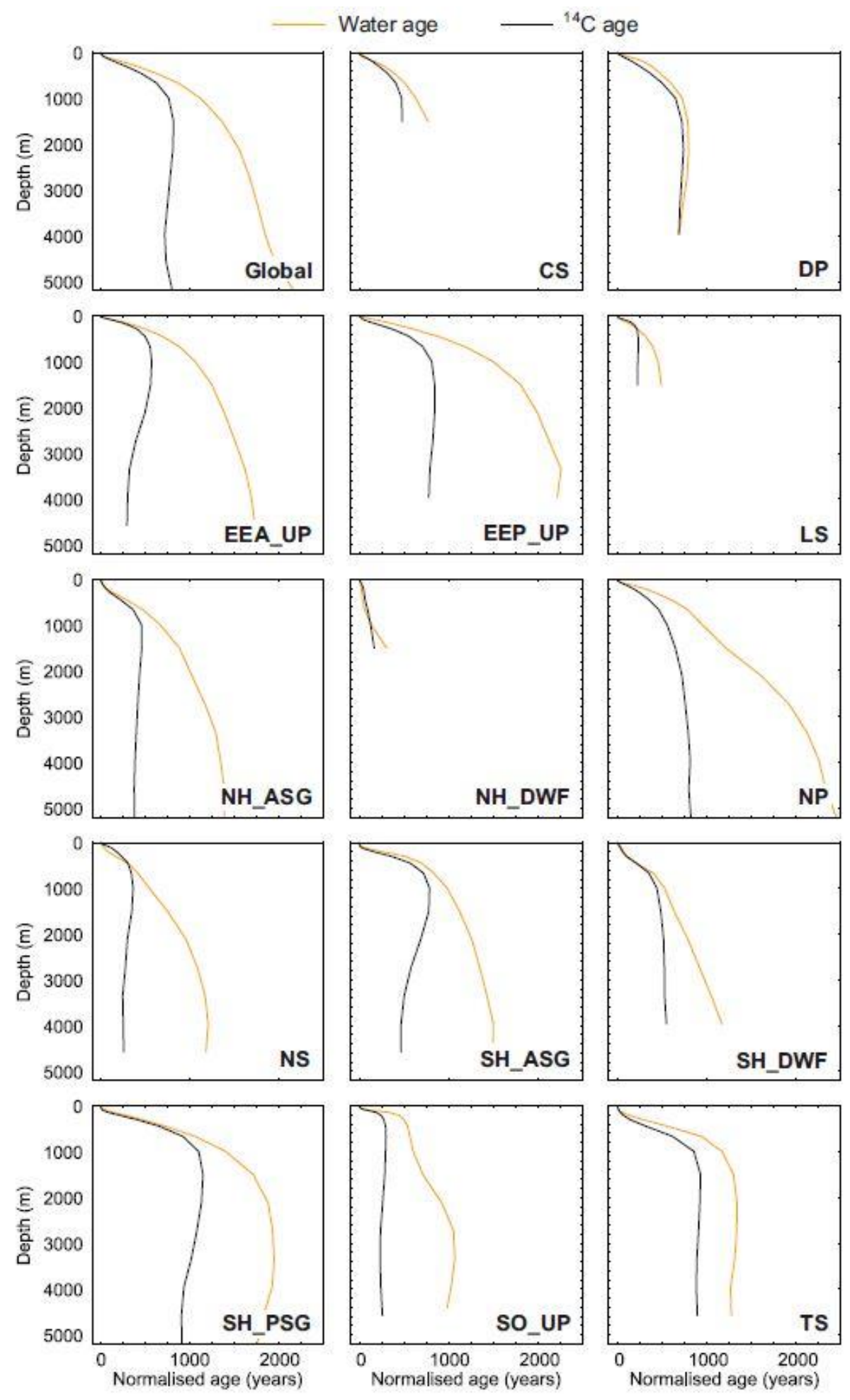

Figure S6: Global and regional depth profiles of water age (orange) and normalised ${ }^{14} \mathrm{C}$ age (black) at the end of the spinup simulation (years 9900 to 10,000 ). The ${ }^{14} \mathrm{C}$ ages have been normalised relative to the surface ocean in each region, so that both the ${ }^{14} \mathrm{C}$ age and the water age in the uppermost layer are 0 years. The regions are outlined in Figure 7 in the main manuscript: Caribbean Sea (CS), Drake Passage (DP), eastern equatorial Atlantic upwelling zone (EEA_UP), eastern equatorial Pacific upwelling zone (EEP_UP), Labrador Sea (LS), Northern Hemisphere Atlantic sub-tropical gyre (NH_ASG), Northern Hemisphere deep water formation region (NH_DWF), North Pacific (NP), Nova Scotia (NS), Southern Hemisphere Atlantic sub-tropical gyre (SH_ASG), Southern Hemisphere deep water formation region (SH_DWF), Southern Hemisphere Pacific sub-tropical gyre (SH_PSG), Southern Ocean upwelling zone (SO_UP), and Tasman Sea (TS). 


\section{References}

Audi, G., Bersillon, O., Blachot, J. and Wapstra, A. H.: The NUBASE evaluation of nuclear and decay properties, Nuclear Physics A, 729(1), 3-128, doi:10.1016/j.nuclphysa.2003.11.001, 2003.

Druffel, E. R. M.: Decade time scale variability of ventilation in the North Atlantic: High-precision measurements of bomb radiocarbon in banded corals, Journal of Geophysical Research: Oceans, 94(C3), 3271-3285, 1989.

Godwin, H.: Half-life of Radiocarbon, Nature, 195(4845), 984, doi:10.1038/195984a0, 1962.

Key, R. M., Kozyr, A., Sabine, C. L., Lee, K., Wanninkhof, R., Bullister, J. L., Feely, R. A., Millero, F. J., Mordy, C. and Peng, T.-H.: A global ocean carbon climatology: Results from Global Data Analysis Project (GLODAP), Global Biogeochem. Cycles, 18(4), GB4031, doi:10.1029/2004GB002247, 2004.

Kilada, R. W., Campana, S. E. and Roddick, D.: Validated age, growth, and mortality estimates of the ocean quahog (Arctica islandica) in the western Atlantic, ICES J Mar Sci, 64(1), 31-38, doi:10.1093/icesjms/fsl001, 2007.

Lee, J.-M., Eltgroth, S. F., Boyle, E. A. and Adkins, J. F.: The transfer of bomb radiocarbon and anthropogenic lead to the deep North Atlantic Ocean observed from a deep sea coral, Earth and Planetary Science Letters, 458, 223232, doi:10.1016/j.epsl.2016.10.049, 2017.

Montero-Serrano, J.-C., Frank, N., Tisnérat-Laborde, N., Colin, C., Wu, C.-C., Lin, K., Shen, C.-C., Copard, K., Orejas, C., Gori, A., De Mol, L., Van Rooij, D., Reverdin, G. and Douville, E.: Decadal changes in the mid-depth water mass dynamic of the Northeastern Atlantic margin (Bay of Biscay), Earth and Planetary Science Letters, 364, 134-144, doi:10.1016/j.epsl.2013.01.012, 2013.

Orr, J., Najjar, R., Sabine, C. L. and Joos, F.: Abiotic-HOWTO. Technical report. Revision: 1.16, [online] Available from: http://ocmip5.ipsl.jussieu.fr/documentation/OCMIP/phase2/simulations/Abiotic/HOWTO-Abiotic.html, 2000.

Orr, J. C., Najjar, R. G., Aumont, O., Bopp, L., Bullister, J. L., Danabasoglu, G., Doney, S. C., Dunne, J. P., Dutay, J.C., Graven, H., Griffies, S. M., John, J. G., Joos, F., Levin, I., Lindsay, K., Matear, R. J., McKinley, G. A., Mouchet, A., Oschlies, A., Romanou, A., Schlitzer, R., Tagliabue, A., Tanhua, T. and Yool, A.: Biogeochemical protocols and diagnostics for the CMIP6 Ocean Model Intercomparison Project (OMIP), Geosci. Model Dev., 10, 2169-2199, 2017.

Palmer, J. R.: The Ocean Carbon Cycle in the Unified Model, 1998.

Scourse, J. D., Wanamaker, A. D., Weidman, C., Heinemeier, J., Reimer, P. J., Butler, P. G., Witbaard, R. and Richardson, C. A.: The marine radiocarbon bomb pulse across the temperate north Atlantic: a compilation of $\Delta 14 \mathrm{C}$ time histories from Arctica Islandica growth increments, Radiocarbon, 54(2), 165-186, 2012.

Sherwood, O. A., Edinger, E. N., Guilderson, T. P., Ghaleb, B., Risk, M. J. and Scott, D. B.: Late Holocene radiocarbon variability in Northwest Atlantic slope waters, Earth and Planetary Science Letters, 275(1-2), 146-153, doi:10.1016/j.eps1.2008.08.019, 2008.

Weidman, C. R.: Development and Application of the Mollusc Arctica Islandica as a Paleoceanographic Tool for the North Atlantic Ocean., unpublished $\mathrm{PhD}$ thesis, Massachusetts Institute of Technology/Woods Hole Oceanographic Institution, MT/WHOI 95-20., 1995.

Weidman, C. R. and Jones, G. A.: A shell-derived time history of bomb 14C on Georges Bank and its Labrador Sea implications, Journal of Geophysical Research, 98(C8), 14577, doi:10.1029/93JC00785, 1993.

Witbaard, R., Jenness, M. I., Van Der Borg, K. and Ganssen, G.: Verification of annual growth increments in Arctica islandica L. from the North Sea by means of oxygen and carbon isotopes, Netherlands Journal of Sea Research, 33(1), 91-101, doi:10.1016/0077-7579(94)90054-X, 1994. 